\title{
Leaving Roman Catholicism
}

\author{
Hugh Turpin
}

\section{1 \\ Introduction}

This chapter presents the Republic of Ireland as a case study in how a once deeply Catholic society is renegotiating its relationship with religion. It draws on my own research to describe the particular style of exit these conditions encourage for those leaving the Catholic Church. Existing Irish secularisation literature demonstrates that changes in social expectations led to a collapse in embodied religiosity. While this has likely reduced the overall transmission and importance of Catholic belief and identity, the Church retains significant institutional influence, supported by widespread "cultural Catholic" affiliation. A series of scandals has acted as a lightning rod for the tensions implicit in this situation, "morally contaminating" the Church and enabling discourse around the rectitude of Catholic affiliation. Together, these contribute to morally charged secularism focussed on severing the default link between Irish ethnic and religious identity to erode lingering Church influence. Against this background, Irish ex-Catholics do not simply leave the Church; many also depict themselves as repudiating "inauthentic" cultural Catholicism which irresponsibly supports the status quo.

\section{Previous Research and Empirical Material}

Catholic population growth exceeds the global average, but the Church is weakening in its old heartlands. Latin American Pentecostalism booms at Catholicism's expense (Robbins, 2004), and 13 percent of the US population describe themselves as former Catholics. ${ }^{1}$ In Europe, Catholicism's cradle, some projections anticipate eventual religious extinction in Catholic states, ${ }^{2}$ surprisingly including "Holy Catholic Ireland", once renowned for its commitment to

1 Pew (2015). America's Changing Religious Landscape. http://www.pewforum.org/2015/o5/12/ americas-changing-religious-landscape/. Accessed 10/3/2017.

2 B BC News. "Religion may become extinct in nine nations, study finds" http://www.bbc.com/ news/science-environment-12811197. Accessed 10/3/2017. 
the One True Church (Fuller, 2002). While excellent work exists on leaving Catholic religious vocations (Ebaugh, 1977, 1984; Hollingsworth, 1985), and on individual disaffiliation trajectories (for the United States, see Hornbeck II, 2011; for Germany, see Knepper, 2012), this chapter adopts a macro-level perspective, examining an example of national departure from Catholic religiosity, and the conflicting social positions that ensue.

Sociologists long considered the Republic of Ireland a pious Western European outlier (Nic Ghiolla Phádraig, 2009), with religiosity more typical of the US (Norris and Ingleharte, 2011). Neo-secularisationists attributed this to Catholicism's key role in defining the national community, an anomalous situation in secularising Western Europe (Bruce, 1992; Taylor, 2007). Antisecularisationists found solace in the Irish case (Ó Féich and O'Connell, 2015; Ganiel, 2016), claiming that the "need to believe" can prevail in the face of declining institutional and public religion (Davie, 1994).

Now, though the majority still identify as Catholic (78.3 percent, Census 2016), self-identification as nonreligious is rising (growing from 269,800 to 468,400 people between 2011 and 2016, a relative increase of 73.6 percent Census, 2016; recent data indicates that 25 percent of $14-25$ year-olds identify as atheist, agnostic or "none" - Barna, 2017). There is little evidence of religious switching (Egan, 2011), unlike in the US (Bottan and Perez-Truglia, 2015). Religious vocations have collapsed (Weafer, 2014), and religious practice is declining rapidly (weekly mass went from 85 percent in 1980 to 35 percent in 2012 - Ganiel, 2016). Agreement with Church moral stances is low (O'Mahoney, 2010; Barna, 2017) and institutional distrust is high (Donnelly and Inglis, 2010). Qualitative work also suggests widespread antipathy towards the Church and religious scepticism outstripping that suggested by surveys (Hilliard, 2003; Inglis, 2014). Outwardly, the Republic must be described as "leaving Catholicism." The most analogous case of large-scale Catholic secularisation may turn out to be Quebec's “quiet revolution” during the 196os (Seljak, 1996), a decoupling of religious and ethnic identity whereby the rejection of Catholicism no longer constituted "ethno-apostasy" (Philips and Kelner, 2006; Deringil, 2012). Yet there is disagreement regarding application of the term "secularisation" in the Irish Catholic case. To understand this, we must examine Irish Catholicism from its peak to the present.

The Irish Catholic "doctrinal revolution" in the mid-19th Century ushered in an era of highly observant Catholicism (Larkin, 1976; Inglis, 1998; Fuller, 2002). Proposed causes include the Famine and consequent population collapse of the rural poor (Connolly, 2001), a cultural identity crisis (Larkin, 1976), the need to limit the fragmentation of inherited landholdings (Inglis, 1998; Connolly, 2001), zealous Church reform (Larkin, 1976; Connolly, 2001), the desire to 
be as "civilised" as the Protestant British (Fuller, 2002), and British support for the Church as a pacifying influence (Inglis, 1998). Larkin portrays a devotional smorgasbord featuring not only regular Mass, confession and communion, but also "the rosary, forty hours, perpetual adoration, novenas, blessed altars, Via Crucis, benediction, vespers, devotion to the Sacred Heart and to the Immaculate Conception, jubilees, triduums, pilgrimages, shrines, processions, and retreats (Larkin, 1976: 77)."

Mass attendance rose to 95 percent, a figure that persisted for almost a century. Clerical pre-eminence was strengthened under the new Republic (1937), the Church's hold reinforced by control of healthcare and education. Writers and social historians describe omnipresent religious inflection, with widespread clericalism and sexual prohibition (McGahern, 1974; Ferriter, 2009; Inglis, 1998). Social capital accrued to those best able to project pious signals, dubbed the "Irish Catholic habitus", cultivated at home by the traditional "Irish mother", who strove to carve out a niche of domestic power within a highly patriarchal society by embodying the Church's picture of feminine virtue (Inglis, 1998). Although scepticism and dissent certainly existed, public and private life was lived in the shadow of the ethno-Catholic sacred canopy.

From the late 196os onwards, cultural and economic globalisation gradually relativised the Faith (Inglis, 1998; Fuller, 2002). Women entered the workforce, reducing female piety and weakening the "priest/mother" religious socialisation alliance. Television provided a new class of cultural commentator over whom the Church eventually lost control. The 7os saw objection to the Church's anti-contraceptive stance (embodied in the papal encyclical $\mathrm{Hu}$ manae Vitae) galvanise the first large-scale emergence of female anti-clerical protest (Forster, 2007; Ganiel, 2016). Vatican II proved disruptive, alienating the aged by overturning cherished rituals and certainties while failing to reign in straying youth (Fuller, 2002; O'Doherty, 2008). For many, practise became almost openly habitual, something Ferriter attempts to capture with the term "practising lapsed Catholics" (Ferriter, 2012).

Though the ethnic tie remained inviolable, the diktats of the Church increasingly seemed anachronistic to youth socialised from the 70s onwards, precipitating the emergence of Catholics less inclined to turn to the Church for moral or spiritual leadership. The Catholic habitus declined; Catholicism "Protestantised", requiring neither outward expression nor the imprimatur of an external authority. Traditional Catholicism became an ageing subculture yielding to purely "cultural" or idiosyncratically "creative" varieties (Inglis, 1998); the majority reconnected with institutional religion sporadically during rites of passage. Privatisation accelerated when clerical sexual abuse of children, cover-ups, and numerous other scandals erupted into the limelight from 
the early 1990s onwards and "tainted the role of the Church as carer, and portrayed it instead as abuser" (Inglis, 1998:227).

Sociological disagreement re-emerges around how to interpret a large majority who identify as Catholic, professing theism while rejecting religious practice and Church moral strictures. Some focus on declining institutional influence and practice to suggest that the Republic fits traditional notions of secularisation quite well (White, 2007; Voas, 2009). Others are more ambiguous (Inglis, 1998; Penet, 2008), while most adopt an optimistic "private Catholicism" model primarily based on high Catholic identification and theistic survey selfreports (Greeley, 1994; Cassidy, 2002; Anderson and Lavan, 2007; Ó Féich and O'Connell, 2015), influenced by Grace Davie's formulation of "believing without belonging" (Davie, 1994). While Church hegemony is unquestionably waning, a recent analysis also concludes that Catholicism may re-evolve to attract "spiritual consumers" within an emerging "religious marketplace" (Ganiel, 2016).

Recent work in the anthropology and psychology of religion encourages greater caution around stable privatised Catholic belief. The embargo on belief within the social anthropology of religion (Needham, 1972; Ruel, 1982) has diminished due to current trends within the anthropology of Christianity emphasising its effortful cultivation (Luhrmann, 2012), requiring us to describe the social mechanisms by which believing is achieved (for example Mair, 2013); current anthropological theory might hesitate to agree that on-paper identification as a believer always amounts to being a believer. Furthermore, survey self-reports may reflect socially desirable responding arising from unreflective "fuzzy fidelity" (Voas, 2009), and Irish data from the European Values Survey (EVs) suggest that the perceived importance of religion is declining alongside practice (cited in Keenan, 2012; Voas, 2009). At the same time, work in the anthropology of Catholicism notes the widespread acceptance of "lapsed" or "cultural" Catholics; identification with Catholicism is often not particularly belief-oriented (Norget et al, 2017). The "optimistic model", however, suggests that non-practicing Irish Catholics tend to be believers because the majority survey-report belief; identificatory and doxastic self-reports are thus fused to yield privatised Catholic theism. Lastly, problems for the optimistic model are also suggested by work on the psychology of religious transmission, which proposes that behavioural displays of commitment (regular ritual participation, financial donation, observation of taboo, and so on) are especially important components in successful intergenerational religious transmission (Henrich, 2009), with initial correlational studies suggesting that exposure to such "credibility enhancing displays" (CREDS) plays a role in determining levels of theism/ atheism (Lanman and Buhrmester, 2016) and intercultural variations in religiosity between otherwise similar cultures (Willard and Cingl, in press). 
My own research investigated the interrelationships between declining practice, Church scandals, and belief. The research consisted of interviews carried out in a number of Dublin parishes with both religious and non-religious individuals, religious personnel, and members of prominent secularist groups, followed by a survey aimed at examining, among other things, the relationship between exposure to parental behaviour indexing Catholic religiosity and the subsequent acceptance of Catholic religious beliefs.

\section{New Findings Focusing on "Leaving Religion”}

Religious informants identified parental failure to "pass on the faith" as crucial to the decline of religiosity, and the survey found the degree to which people perceived their parents' actions to be motivated by religious belief was the best predictor of acceptance of theism, orthodox Catholic belief, and Catholic social identification. Furthermore, it appeared that younger cohorts perceived parental behaviour to be less motivated by religion (Turpin, forthcoming). This could suggest that the replacement of embodied doctrinal Catholicism with the internalised variety proposed by Irish sociologists constitutes a reduction in the embodied transmission of Catholic belief and identity. Catholic "believing without practicing" may be a transitory bridge to unbelief (for example Voas, 2009) rather than a new, transmissible form of religiosity (for example Davie, 1994).

More devout privatised Catholicism also rewards investigation. Informants who retained strong Catholic belief and identity but also rejected the moral leadership of the institutional Church tended to report a Catholic upbringing to which they felt some need to maintain a link; it was "their culture" (see also Egan, 2011; Inglis, 2014). Thus, some de-institutionalised Catholicism could issue from a temporary species of "cross pressure" (Taylor, 2007) where a deeply rooted social identification with Catholicism conflicts with a more liberal environment and values. A privatised interpretive "take-over" from the Church resolves this dissonance, allowing "modernity" to be embraced and Catholic identification retained, albeit relatively unexpressed. However, for subsequent generations receiving lower "CRED exposure" as a result, Catholicism will constitute a more alien supernatural product. Thus, even if a post-Catholic "religious marketplace" should emerge, the Catholic share of that marketplace is far from guaranteed.

This overall situation might entail only a fade into something functionally analogous to an established state church such as in the UK; secularisationists such as Demerath (2000) and Voas (2009) describe how European 
secularisation trajectories can plateau at a minimally committed state of "cultural religion", perhaps a plausible destiny in any society where religious and ethnic identity are so intertwined. However, such a trajectory is complicated by two further interconnected factors: moral inversion and lingering influence.

Whereas non-religion in some Western European contexts is characterised as apathetic (Zuckerman, 2008), in the Republic it is often self-conscious and charged; Catholicism is ever an issue (Ganiel, 2016), and many ex-Catholics view the Church and Catholicism in a highly negative moral light, as comprehensively expressed by the following ex-Catholic informant:

It has created a lot of guilt and oppression for generations. It has been used to control and punish people and has slowed down the country's intellectual and economic development. It has particularly had a negative effect on women's rights and helped to establish the view that all women are seen either as virgins, mothers or whores and that they do not hold the rights to their own bodies, either in terms of sex or reproduction (which are two separate things). It held such a choke-hold on the country that it was able to, for years, facilitate the physical, sexual and psychological abuse of children by hypocritical authoritarian priests who preached one thing and did another and whose offences were routinely covered up as a matter of course in a society where lay people feared speaking out against the regime of the Catholic Church.

This antipathy also emerges in an analysis of 2008 EVs data from 14 western European countries; the Republic had both the strongest anti-religious sentiment and the widest endorsement of religion (Ribberink et al., 2013). We can speak both of a growing self-consciously anti-religious minority and a larger vaguely "pro-religious" group who retain a Catholic identity while nevertheless rejecting the Church: a 2011 survey by the conservative Catholic Iona Institute found that almost half ( 47 percent) of the population had a negative view of the Church, and 25 percent would be unperturbed if it disappeared entirely. ${ }^{3}$

This widespread negative view may be motivated by a mixture of distrust (Donnelly and Inglis, 2010) and rejection of moral conservativism (Barna, 2017). Donnelly and Inglis found that trust in the Church had decreased more quickly in Ireland than in other European Catholic societies since the 1990s. The Iona data relate this attitudinal shift to sexual and institutional abuse revelations

3 "Attitudes Towards the Catholic Church," http://www.ionainstitute.ie/wp-content/uploads/ 2014/11/Attitudes-to-Church-poll.pdf. Accessed 10/3/2017. 
(Iona, 2011). My own survey on rejection factors found that moral conservativism and clerical abuse were the two most emphasised factors in disaffiliation. Compared to other Catholic societies, the effect of the scandals is likely amplified in Ireland as the Church's prior moral hegemony foregrounds the hypocrisy of its fall from grace (Inglis, 1998; Hilliard, 2003; Keenan, 2012).

The depletion of religious practice has likely been exacerbated by such revelations; many attribute their own declining religious participation to Church scandals (Hilliard, 2003), with practice declining more swiftly over the "era of scandal" than the preceding decades (Donnelly and Inglis, 2010; Bottan and Perez-Truglia, 2015). Clerical interviewees, too, corroborated this picture, describing wavering religious confidence among even "old, faithful people." At the interpersonal level, family religious pressure became easier to resist (Hilliard, 2003), and some devout individuals withdrew in shame from the established mechanisms of public theistic expression (Egan, 2011). For instance, one non-religious informant recalled successfully resisting his mother's attempts to force him to Mass as a teenager: "There I was with my Ma banging on the bathroom door and I says to her, I says, 'Why the fuck should I go there and listen to that bunch of paedophile priests and the paedophile nuns that protect them?"

Whether clerical abuse has directly accelerated declining religiosity or has acted to provide a cultural narrative legitimising a socially tense transformation that was already well underway is an uncertain matter. It is likely that the scandals fell on fertile ground (O'Doherty, 2008), empowering religious resistance and perhaps even drawing latent moral opposition into acute conscious awareness (Keane, 2015), precipitating exit from a default cultural Catholicism often described to me as marked by experiences of boredom, irrelevance, and transparent social conformism. At the same time, some traditional or conservative Catholics have incorporated such reactions into their own narratives, maintaining that the scandals were widely exploited to abandon religious participation: as one conservative priest phrased it, "those who were looking for an excuse to leave got what they wanted very nicely."

While some priests were particularly daunted by situations that required them to go into Dublin city centre in clerical attire, maintaining that a trend had emerged for priests to go "incognito" in secular clothing, a "very Irish thing" (see also Goode et al, 2003, for priestly attire as "paedophile uniform"), I also encountered the view that overt hostility "peaked around 10 or 15 years ago... we've mostly moved beyond that sort of thing now." Irish society cannot be said to have moved back though. Habituation to religious scandal is evident from its presence in comedy (for example, in the work of Dublin comedian David McSavage) and noir-tinted period drama, with the alliterative term "paedo 
priest" long since etched into public consciousness. ${ }^{4}$ Paradoxically, the "paedo priest" trope can even be instrumentalised to legitimise staying Catholic while rejecting hierarchical claims to authority on Catholicism's meaning. Liberated from subordination to a corrupt clergy's theology, a self-tailored "moral therapeutic deism" can be inserted into the socially-approved husk of ethnic Catholic affiliation (for example Smith, 2005). Given the sheer salience of clerical abuse, intergroup distinctions may lie not in levels of awareness but rather by how the "taint" is handled by various actors to legitimise their orientation towards Catholic belief and identification.

What we can say with greater certainty is that the Church's "moral taint" means that committed engagement now requires more justification (for example Ganiel, 2016; Egan, 2011). This is a problem for committed Catholics, whose moral intuitions (for example Haidt and Joseph, 2004) can pull in different directions: they may evoke disgust while being compelled to remain loyal to their religious identity, with various reconciliation strategies addressing this "moral dissonance." "Bad apple" theories quarantine the moral taint from the institutional Church. Deflection strategies emphasise feelings of personal victimhood, repositioning Catholics as a vulnerable and stigmatised group at the mercy of those who are "anti-Church, anti-religion, anti-everything, really", as one young Catholic woman averred, and as manifests repeatedly in conservative Catholic media discourse defending a cowed "silent majority" against a liberal elite cabal intent on hastening secularisation - for instance, one conservative Catholic media article prophesised a futuristic Orwellian scenario where Irish Catholics would have to identify one another with secret handshakes and symbols. Alternatively, the mainstream Church, and with it the taint, can be rejected outright, with reformist splinter factions embraced instead. Conversely, the taint can be spread wide, and a complicit society constructed as scapegoating the Church. The range of these self-conscious justificatory strategies highlights the fragmentation and inefficacy of Catholic narratives in forming popular consensus (for example Haidt and Joseph, 2004; Keane, 2015); such viewpoints lack large scale media exposure and are easily branded "excuses", or brushed off as "brainwashed" or "conspiracist."

Secular narratives by contrast are powerfully reinforced by scandal, offering the opportunity, the duty, of liberation from the clucthes of a repressive past. Whereas this "revisionist view" was once the province of a minority (Ruane, 1998), it has long since spread out on wings of scandal (Browne, 2012): exCatholicism is now a powerful moral stance. An example of this is the following

4 For instance: https://www.joe.ie/uncategorized/paedo-priests-face-slashed-in-prison-13635. Accessed 4/11/2017. 
testimony from an ex-Catholic in her thirties. Initially describing her incredulity about a society which permitted "priests running around killing women and children. Like, separating women and children, selling babies, then burying them in mass graves and then ugh, God!", she describes her feelings around a family member's acquiescence in cultural Catholic practices:

Yesterday, my sister baptised her second child. I am disgusted. I'm sure it was the first time she has been in a church since the baptism of her first child, before that, her wedding. I'm sure the real reason is to fit in, or to please my older family members, not that they would have asked her to do it. Maybe because she's not sure about what to believe. Maybe she wants to be able to get the kids into a school more easily...the reason is definitely not because she believes... although she would argue that it is, to defend her actions.

We can see from the frustration evident above that full secularisation is impeded by the fact that the vast majority continue to identify as Catholic, seen as preserving Church influence consolidated during a more religious age. This perception that the Church is both waning and retaining influence allows for the simultaneous existence of strong anti-religion among the non-religious and vestigial Catholicism in the larger "Church rejecting" block. Indeed, Church influence could be sustained by its increased subordination; lacking the same level of dictatorial strength, it is more easily ignored and tolerated, called upon when needed. Older people in particular still turn to it for a sense of community and comfort, generating pressure on family members not to disturb them by openly defecting, and a large majority continue to enjoy traditional Catholic rites of passage. Indeed, the sheer centrality of these to Irish social identity has led the Church to strategise that this "anthropological link" might be exploited as a means of re-evangelisation, ${ }^{5}$ perhaps explaining its tenacious hold on the education system, where it strives to impart Catholic beliefs, rituals, and values disregarded by increasingly disengaged parents.

The devout thus exhort cultural Catholics to find their faith, while secularists encourage them to drop their passive support for a morally reprehensible institution, meaning Irish ex-Catholicism is perhaps notable for its propensity to define itself in opposition to cultural religion as much as devout religion. Though nonchalant popular Catholicism could be viewed as a strategic

5 Where is your God? Responding to the Challenge of Unbelief and Religious Indifference Today. Concluding Document of the 2006 Plenary Assembly. http://www.cultura.va/content/cul tura/en/pub/documenti/whereisyourgod.html. Accessed 4/2/2017. 
triumph, allowing individuals to take what they want from a humbled Church, the compromise causes problems for those who seek a more complete breach. Ongoing confusion around Catholic census identification, for example, is compounded by the fact that 9o percent of primary schools are under Catholic Church patronage, creating difficulties for those wishing to raise children without what one side describes as religious indoctrination and the other, faith formation. The key objective for some secularist groups is to drive down habitual Catholic identification among the inertial middle, dislodging the hold of the Church and ridding society of institutional-religious obstacles and Catholicism-inflected laws. A prime mechanism for this is drawing attention to the Church's hypocrisies, which provide potent content for getting "complacent Catholics" to reassess a "contaminated" affiliation.

The 2017 Tuam scandal provided a particularly clear example of such "weaponisation." Archaeologists employed by a commission of enquiry discovered a "significant amount" of infant remains interred in a decommissioned septic tank at a former home for "unmarried mothers" run by the Bon Secours nuns. This prompted a surge in public condemnation, energising online secularist groups in particular. Responses were characterised by moral disgust, with the entire Church frequently portrayed as contaminated. There was chagrin that religious acquaintances could remain associated with such a "murderous" institution, even promising to "pray for the little babies." Petitions emerged demanding the re-introduction of an official mechanism for de-baptism and an end to Church educational and health involvement. Apart from religious institutions themselves, the strongest antagonism coalesced around conservative spokespeople shifting blame from Catholicism onto general society, and habitual Catholics constructed as oblivious enablers of ongoing clerical domination. This new wave of scandal potentially describes Catholicism itself almost as a moral infection, distinguishing it from "quarantinable" clerical sexual abuse. It also further contributes to the de-legitimisation of the majority cultural Catholic default. Whether or not greater numbers of the "inertial middle" drop a Catholic affiliation thereby precipitating acceleration in the Republic's institutional secularisation remains to be seen.

\section{Conclusion}

This chapter sought to provide a case study of how a once particularly Catholic society can now be said to be leaving Catholicism. While much of the existing literature argues that Ireland is best viewed as merely dropping public practice while privatising Catholic belief, I have argued that continuing reduction 
in embodied displays of religiosity is reducing the overall importance and transmission of Catholicism. Meanwhile a series of scandals has morally contaminated the Church, rendering devout Catholicism something that must be explained. Despite this, the Church retains significant influence in certain areas of Irish life, and the majority continue to think of themselves as Catholic, at least in an ethnic sense. Together, these contribute to a strident secularist minority focussed on severing the default link between Irish ethnic and religious identification in order to erode lingering Church control. This dynamic is likely to persist into the future.

\section{References}

Andersen, K., and Lavan, A. 2007. "Believing in God but not Obeying the Church: Being a Catholic in Ireland and Poland in the 199os." In B. Hilliard, and M. Nic Ghiolla Phádraig, eds., Changing Ireland in International Comparison. Dublin: The Liffey Press.

Bottan, N.L., and Perez-Trugia, R. 2015. "Losing my Religion: The Effects of Religious Scandals on Religious Participation and Charitable Giving." Journal of Public Economics. 129 (C), 106-119.

Brown, C. 2012. Religion and the Demographic Revolution: Women and Secularisation in Canada, Ireland, UK and USA Since the 196os. Boydell Press: Woodbridge.

Cassidy, E. 2002. "Modernity and Religion in Ireland: 1980-2000." In E. Cassidy, ed, Measuring Ireland:Discerning Beliefs and Values. Dublin: Veritas.

Connolly, S.J. 2001. Priests and People in Pre-Famine Ireland, 1780-1845. Dublin: Four Courts.

Demerath III, N.J. 2000. “The Rise of 'Cultural Religion' in European Christianity: Learning from Poland, Northern Ireland and Sweden." Social Compass. 47:1, 127-139.

Deringil, S. 2012. Conversion and Apostasy in the Late Ottoman Empire. Cambridge: Cambridge University Press.

Donnelly, S. and Inglis, T. 2010. "The Media and the Catholic Church in Ireland: Reporting Clerical Child Sex Abuse." Journal of Contemporary Religion. 25:1, 1-19.

Ebaugh, H.R.F. 1977. Out of the Cloister: A Study of Organizational Dilemmas. Austin: University of Texas Press.

Ebaugh, H.R.F. 1984. Becoming an Ex: The Process of Role Exit. Chicago: University of Chicago Press.

Egan, K. 2011. Remaining a Catholic after the Murphy Report. Dublin: Columba Press.

Fahey, T. 2002. "Is Atheism Increasing? Ireland and Europe Compared." In E. Cassidy, ed, Measuring Ireland:Discerning Beliefs and Values. Dublin: Veritas. 
Fuller, L. 2002. Irish Catholicism since 1950: The Undoing of a Culture. Dublin: Gill and MacMillan.

Ferriter, D. 2009. Occasions of Sin: Sex and Society in Modern Ireland. London: Profile Books.

Ferriter, D. 2012. Ambiguous Republic: Ireland in the 1970s. London: Profile Books.

Forster, R.F. 2007. Luck and the Irish: A Brief History of Change. Oxford: Oxford University Press.

Ganiel, G. 2016. Transforming Post-Catholic Ireland: Religious Practice in Late Modernity. Oxford: Oxford University Press.

Greeley, A. 1994. “Why do Catholics Stay in the Church?” The Furrow. 45:9, 495-502.

Haidt, J. and Joseph, C. 2004. "Intuitive ethics: How innately prepared intuitions generate culturally variable virtues.” Daedalus. 133:4, 55-66.

Henrich, J. 2009. "The evolution of costly displays, cooperation, and religion: Credibility enhancing displays and their implications for cultural evolution." Evolution and Human Behaviour. 30, 244-26o.

Hilliard, B. 2003. "The Catholic Church and Married Women's Sexuality: Habitus Change in the Late 2oth Century Ireland." Irish Journal of Sociology. 12.2, 28-49.

Hollingsworth, G. 1985. Ex-Nuns: Women who have Left the Convent. Ann Arbor: University of Michigan Press.

Inglis, T. 1998. Moral Monopoly: The Rise and Fall of the Catholic Church in Modern Ireland. Dublin: University College Dublin.

Inglis, T. 2007. "Catholic Identity in Contemporary Ireland: Belief and Belonging to Tradition." Journal of Contemporary Religion. 22:2, 205-220.

Inglis, T. 2014. Meanings of Life in Contemporary Ireland: Webs of Significance. Basingstoke: Palgrave MacMillan.

Irish Census 2011. This is Ireland - Highlights from Census 2011, part 1.

Keane, W. 2015. Ethical Life: Its Natural and Social Histories. Princeton: Princeton University Press.

Keenan, M. 2012. Child Sexual Abuse and the Catholic Church: Gender, Power and Organisational Culture. Oxford: Oxford University Press.

Lanman, J.A. and Buhrmester, M. 2016. "Religious Actions Speak Louder than Words: Exposure to CREDs Predicts Theism." Religion, Brain and Behaviour. 6, $3^{-16 .}$

Larkin, E.J. 1976. The Historical Dimensions of Irish Catholicism. CUA Press.

Luhrmann, T. 2012. When God Talks Back: Understanding the American Evangelical Relationship with God. New York: Vintage.

Mair, J. 2013. "Cultures of Belief." Anthropological Theory. 12:4, 448-466.

McGahern, J. 1974. The Leavetaking. London: Faber and Faber.

Needham, R. 1972. Belief, Language and Experience. Oxford: Blackwell. 
Nic Ghiolla Phádraig, N. 2009. "Religion in Ireland: No Longer an Exception?" ARK NI Research Update, 64.

O' Doherty, M. (2008). Empty Pulpits: Ireland's Retreat from Religion. Dublin: Gill Books.

Ó Féich, P., and O'Connell, M. 2015. "Changes in Roman Catholic Beliefs and Practices in Ireland between 1981 and 2008 and the Emergence of the Liberal-Catholic." Journal of Contemporary Religion. 30, 38-54.

O'Mahoney, E. 2010. Religious Practice and Values in Ireland - A Summary of the European Values Study 4 th wave data, Irish Catholic Bishop's Conference.

Penet, J. 2008. From Idealised Moral Community to Real Tiger Society. The Catholic Church in Secular Ireland. Estudios Irlandeses. 3, 143-153.

Philips, B.T., and Kellner, S. 2006. "Reconceptualizing Religious Change: EthnoApostasy and Change in Religion Among American Jews." Sociology of Religion. 67:4, 507-524.

Ribberink, E., Achterberg, P. and Houtman, D. 2013. "Deprivatization of Disbelief?: Non-Religiosity and Anti-Religiosity in 14 Western European Countries." Politics and Religion. 6, 101-120.

Robbins, J. 2004. "The Globalization of Pentecostal and Charismatic Christianity" Annual Review of Anthropology. 33, 117-143.

Ruane, J. 1998. "Secularisation and Ideology in the Republic of Ireland." La Secularisation en Irlande. Caen: Presses Universitaires de Caen, 239-254.

Ruel, M. 1982. "Christians as Believers", in Davis, J. (ed), Religious Organisation and Religious Experience. London: Academic Press.

Seljak, D. 1996. “Why the 'Quiet' Revolution was Quiet: The Catholic Church's Reaction to the Secularization of Nationalism in Quebec after 196o." CCHA Historical Studies. $62,109-124$.

Smith, C. 2005. Soul Searching: The Religious and Spiritual Lives of American Teenagers. Oxford: Oxford University Press.

Sperber, D. 1996. Explaining Culture: A Naturalistic Approach. Oxford: Blackwell.

Taylor, C. 2007. A Secular Age. Cambridge: Harvard University Press.

Taylor, L.J. 1995. Occasions of Faith: An Anthropology of Irish Catholics. Dublin: Lilliput Press.

Turpin, H. (manuscript in preparation). "Contemporary Irish Attitudes towards the Catholic Church."

Weafer, J.A. 2014 Thirty-Three Good Men: Celibacy, Obedience and Identity. Dublin: Columba Press.

White, T.J. 2007. "Catholicism and Nationalism in Ireland: From Fusion in the 19th Century to Separation in the 21st Century." Westminster Papers in Communication and Culture. 4:1, 47-64.

Willard, A.K. and Cingl, L., (in press) "Testing Theories of secularization and religious belief in the Czech Republic and Slovakia." Evolution and Human Behavior. 
Win-Gallup International Index of Religion and Atheism, 2012.

Voas, D. 2009. "The Rise and Fall of Fuzzy Fidelity in Europe" European Sociological Review. 25:2, 155-168.

Zuckerman, P. 2008. Society Without God: what the least religious nations can tell us about contentment. New York: New York University Press. 